\title{
Kehadiran Subkultur Klub Motor di Ruang Publik Kota Bandung
}

\author{
Nurhijrah \\ Fakultas Teknik, Universitas Andi Djemma Palopo \\ Nurhiijrah.rie@gmailcom
}

\begin{abstract}
ABSTRAK
Kehadiran subkultur dalam kehidupan masyarakat perkotaan merupakan hasil dari heterogenitas kebudayaan dalam suatu kota. Salah satu subkultur yang terdapat di Kota Bandung ialah klub motor yang dapat ditemui hampir disetiap sudut Kota Bandung termasuk di ruang publik. Penelitian ini dilakukan untuk meng-identifikasi fenomena subkultur klub motor dan proses okupansi ruang terbuka publik yang dilakukan oleh subkultur tersebut di Kota Bandung. Pengumpulan data dilakukan dengan cara observasi dan wawancara anggota subkultur kub motor yang menjadi subjek penelitian dan kemudian dianalisis dengan cara deskriptif. Hasil analisis menunjukkan bahwa motif utama penggunaan ruang terbuka publik di bawah fly over tersebut karena adanya keinginan eksistensi diri namun tidak dapat diwadahi pada ruang terbuka publik kota yang sudah ada. Pengokupasian ruang yang dilakukan oleh klub motor memberikan makna baru pada ruang yang awalnya tidak memiliki fungsi dalam tata ruang kota, namun secara tidak langsung juga melakukan legitimasi kekuasaan terhadap ruang. Dari fenomena tersebut, para arsitek dan perencana kota seharusnya mempertimbangkan kehadiran subkultur tersebut sebagian bagian masyarakat Kota Bandung dan mempunyai hak yang sama dalam akses penggunaan ruang terbuka publik Kota.
\end{abstract}

Kata kunci: Okupansi Ruang Publik, Subkultur, Klub motor, Ruang publik

\section{ABSTRACT}

The presence of subcultures in urban society is as a result of the heterogeneity of culture. One of subculture that presence in Bandung city is a motorcycle club which can be found in almost every corner of the Bandung city, especially in public spaces. This study was conducted to identify the phenomenon of the process of motorcycle club subculture occupy space in public open space under flyover in Bandung city. Data was collected by observation and interview members of the subculture as a subject of the research. The result showed that the main motive for using public open space under flyover is the desire for self-existence that cannot be accommodated in public space that already exists. Utilization of the space under flyover by the motorcycle club gives new meaning to the space that originally did not have a function in urban spatial. However they also do legitimacy of power over space by said that "the space is theirs". Therefore architects and planners should consider subculture as a part of the society that have the same right to access public open space and do their activities in Bandung City.

Keywords: Subculture, Motorcycle Club, Public space

\section{Pendahuluan}

Masyarakat perkotaan terdiri dari berbagai latar belakang, suku, agama, ras dan kebudayaan yang berbeda. Keberagaman tersebut memicu terbentuknya beberapa subkultur didukung oleh adanya kesamaan tujuan dan pandangan terhadap sesuatu dalam cakupan wilayah tertentu. Dalam masyarakat yang kompleks, subkultur tersebut 
berjuang untuk legitimasi bagi kebiasaan-kebiasaan dan nilai-nilai hidup yang menentang kebudayaan dominan.

Adanya subkultur-subkultur di tengah masyarakat tentu saja menimbulkan beberapa dampak, baik itu positif maupun negatif. Dampak negatifnya yaitu perilaku subkultur yang bersifat menyimpang, biasanya meresahkan dan menimbulkan konflik di tengah masyarakat. Sedangkan dampak positifnya, antara lain menciptakan toleransi antara budaya dominan dengan marjinal dalam masyarakat perkotaan.

Karakter masyarakat kota Bandung yang memang senang akan perubahan dan perbedaan, membuat keberadaan subkultur dapat terlihat pada di hampir setiap sudut kota Bandung. Salah satu subkultur yang cukup identik dengan Kota bandung ialah klub motor.

Klub motor adalah satu wadah yang dapat menampung aspirasi serta keinginan para anggotanya berdasarkan mufakat dan kesepakatan pada waktu awal pembentukan. Klub motor pada umumnya memiliki maksud dan tujuan tertentu dan struktur organisasi yang jelas. Gerombolan sepeda motor serta kebisingan pengendara mengekspresikan kebudayaan nilai dan identitas dari klub motor. Keteraturan dari klub motor inilah yang menjadi pembeda dengan kelmpok geng motor yang banyak mendapatkan citra negatif dari masyarakat.

Sebagai cara untuk menunjukkan eksistensi dirinya, klub motor membutuhkan wadah (ruang) sebagai tempat berkumpul. Salah satu ruang yang telah dikenal identik dengan keberadaan klub motor di Kota Bandung ialah ruang dibawah flyover Jalan Cikapayang. Keberadaan klub motor pada ruang yang cukup strategis tersebut, memberikan citra tersendiri terhadap wajah Kota Bandung.

Pada dasarnya ruang pubik merupakan ruang yang dapat diakses oleh semua orang. Ruang publik pun digunakan sebagai wadah interaksi sosial antar masyarakat. Pada umumnya ruang public di bawah fly over dimanfaatkan untuk aktivitas parkir, pedagang kaki lima dan pejalan kaki. Pada penelitian ini ruang publik dibawah flyover Jalan Cikapayang dimanfaatkan untuk kegiatan berkumpul oleh suatu komunitas tertentu yaitu klub motor.

Terdapat beberapa faktor yang mempengaruhi terjadinya aktivitas dibawah fly over yaitu (Susanti, 2014): 1). Lokasi ruang terbuka public, 2) Munculnya terminal bayangan di sekitar ruang terbuka publik. 3) Fungsi bangunan di sekitar ruang terbuka publik. 4) Desain ruang terbuka publik di bawah jembatan layang. 5) Peraturan pemerintah yang belum mampu mengatur tentang pedagang kaki lima. Adapun penelitian dari Rahma \& Somaatmadja (2013) menyebutkan bahwa pemanfaatan ruang di bawah fly over karena faktor ruang itu sendiri yang memberikan privasi bagi orang yang berada di dalamya.

Pemanfaatan ruang terbuka di bawah flyover yang dilakukan oleh klub motor secara rutin memberikan kesan adanya privatisasi ruang publik. Privatisasi ruang publik menyebabkan meningkatnya segregasi sosial, serta terbentuknya kelompok eksklusif dan berbagai masalah sosial lainnya (Santoso, 2006). Penelitian ini dilakukan untuk mengidentifikasi fenomena subkultur klub motor dan proses okupansi ruang terbuka publik yang dilakukan oleh subkultur tersebut di Kota Bandung.

\section{Metode}

Penelitian ini dilakukan dengan metode deskriptif dengan teknik survey lapangan, yaitu dengan cara melakukan observasi secara langsung ke ruang terbuka dibawah flyover Jl. Cikapayang Bandung dan mengajukan pertanyaan kepada subjek penelitian yaitu klub motor Bandung. Pengumpulan data dilakukan dengan teknik wawancara tidak terstruktur dan dokumentasi foto, yang dilakukan pada waktu malam hari di akhir pekan 
(Hari Jumat dan Sabtu). Data yang telah dikumpulkan kemudian dianalisis secara deskriptif untuk memberikan gambaran bagaimana subkultur klub motor menempati ruang terbuka publik di Kota Bandung.

\section{Hasil dan Pembahasan}

\subsection{Subkultur Klub Motor di Kota Bandung}

Bandung merupakan salah satu kota yang dikenal akan banyaknya keberadaan klub motor. Keberadaan klub motor di Kota Bandung bukan merupakan fenomena baru, akan tetapi telah dimulai dari tahun 1980-an, yaitu pada saat terbentuknya klub motor Broterhood yang asalnya merupakan kumpulan para penggemar motor tua, De Motor'87.

Secara umum klub motor yang ada di Kota Bandung memiliki bentuk dan jalur koordinasi yang sama, serta memiliki pemahaman yang didasarkan idealiasme yang tinggi. Klub tersebut hadir dari satu habitat atau ketertarikan yang sama, misalnya satu merek motor dari satu pabrikan tertentu. Semakin banyaknya produk motor yang muncul dari pihak produksi akan memicu munculnya komunitas atau club motor yang baru.

Klub motor di Bandung terdiri dari berbagai latar belakang yang berbeda, seperti mahasiswa dan pekerja kantoran. Dalam perekrutan anggota klub, yang menjadi rioritas dan syarat utama bagi calon anggota yakni kepemiliki Surat Izin Mengemudi (SIM C) dan Surat Tanda Nomor Kendaraan Bermotor (STNK) serta kendaraan. Kelengkapan administrasi tersebut sangat penting bagi para untuk menjalin kerjasama antara klub motor dan pihak berwajib. Kerjasama tersebut diperlukan agar klub motor tersebut dapat terdaftar dan dianggap sebagai suatu aktivitas positif di perkotaan.

Selain kegiatan berkumpul sercara rutin, berbagai aktivitas positif yang biasanya dilakukan oleh klub motor, seperti bakti sosial, pelatihan keselamatan berkendara, kewirausahaan, serta ikut serta menyosialisasikan program penghijauan. Namun, citra klub motor bagi masyarakat umum tidak selalu baik karena banyaknya pemberitaan tindakan kriminal yang disebutkan dilakukan oleh komunitas motor di berbagai media. Pemberitaan tersebut tentu saja membuat citra klub motor di bandung menjadi negatif. Oleh karena itu, klub-klub motor di Bandung berusaha memulihkan kembali nama baik mereka melalui berbagai kegiatan positif yang terus dilakukan.

\subsection{Klub Motor dan Ruang Terbuka Publik di Kota Bandung}

Salah satu kegiatan yang dilakukan oleh klub motor di Bandung ialah kegiatan kopi darat atau sering disebut dengan istilah kopdar, yaitu kegiatan dimana semua anggota klub saling berkumpul pada hari yang telah di tentukan. Kegiatan ini merupakan salah satu kegiatan wajib yang diatur dalam peraturan tiap klub. Pada beberapa klub motor terdapat kewajiban bagi anggota baru untuk mengikuti kegiatan kopdar minimal dua kali agar dapat menjadi anggota resmi.

Kegiatan kopdar yang dilakukan oleh klub motor ini biasanya dilakukan pada ruang terbuka publik di Kota Bandung. Pada penelitian ini, fokus ruang publik yang biasa digunakan oleh klub motor di Bandung ialah pada ruang publik di bawah fly over Jl. Cikapayang Kota Bandung. 


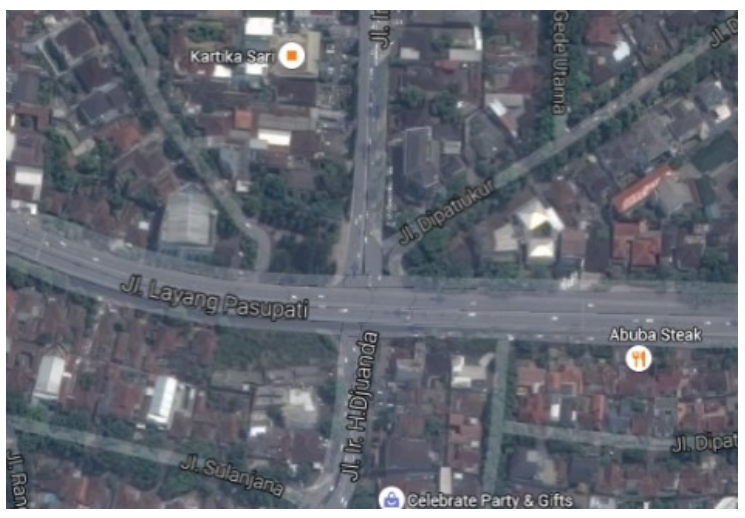

Gambar 1. Lokasi Penelitian Jl. Ir. H. Juanda - Jl. Cikapayang Kota Bandung (Sumber: Google Maps, 2018)

Pada tahun 2012 walikota Bandung, melakukan usaha penataan ruang dibawah flyover. Berbagai upaya dilakukan seperti pembuatan taman-taman tematik yang didesain dengan baik serta dilengkapi dengan perabot ruang seperti tempat duduk dan fasilitas pelengkap lainnya. Adapun ruang di bawah flyover yang terdapat dipersimpangan Jl. Cikapayang - Jl. Merdeka - Jl. Ir H. Juanda hanya dirapikan dengan pemasangan paving block sebagai penutup lantai, dan tidak didesain sebagai taman kota.

Ruang di persimpangan tersebut pada akhirnya menjadi ruang tanpa "identitas". Beberapa ahli urban mendefinisikan ruang tersebut sebagai ruang "sisa" yang tercipta akibat proses industrialisasi di perkotaan. Ruang ini biasanya ditemui pada pinggir rel kereta api, bekas pabrik, dibawah jembatan daln lain-lain. Akibat dari tidak adanya identitas kepemilikan pada ruang tersebut, mebuat sifat ruangnya yang lebih bebas sehingga siapapun memiliki hak untuk mengokupasi ruang tersebut. Pada ruang ini, okupansi dilakukan oleh beberapa klub motor di Kota Bandung.

Dari hasil wawancara yang dilakukan diketahui bahwa klub motor yang pertama kali menempati ruang ini ialah Suzuki Satria M150 Club (SSMC) (lihat Gambar 2), yaitu dari awal pembentukan klub di tahun 2008. Dari hasil wawancara dengan salah satu anggota klub terlama, diketahui bahwa alasan pemilihan ruang ini ialah karena letaknya yang strategis dan mudah dilihat oleh orang lain. Adanya keinginan suatu subkultur untuk memperlihatkan eksistensi dirinya di tengah masyarakat, membuat faktor visibilitas dari ruang menjadi penting. Pada ruang ini, klub motor dapat dengan mudah menunjukkan identitas dirinya sehingga dapat menarik orang lain yang ingin bergabung dengan klub mereka.
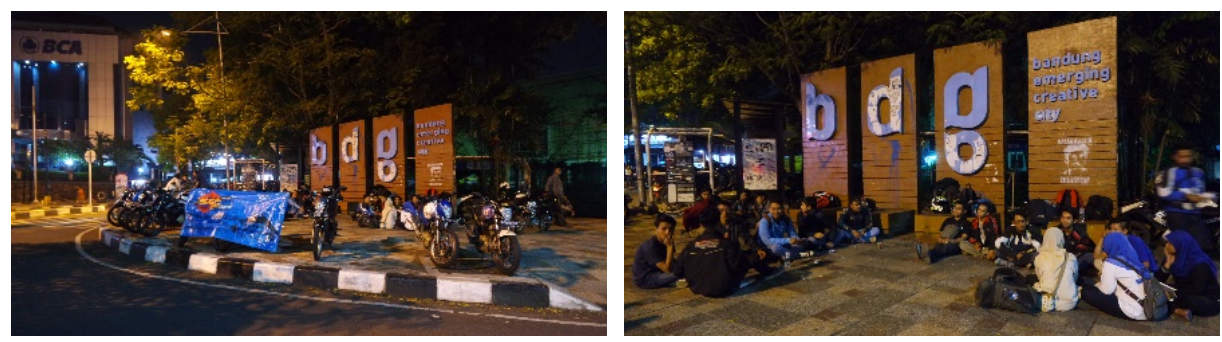

Gambar 2. Klub Motor SSMC di ruang publik Kota Bandung

Dalam upaya mengokupasi ruang terbuka ini, klub motor SSMC melakukan berbagai upaya, salah satunya ialah dengan menempati ruang tersebut secara rutin, sehingga orang lain dapat menyadari kehadiran mereka dan mengidentifikasikan ruang tersebut dengan keberadaan mereka. Sehingga seolah-olah ruang tersebut telah menjadi milik klub motor SSMC pada hari dan waktu tersebut. 
Cara lainnya yang ditempuh ialah dengan meminta izin kepada pihak berwenang. Namun karena ruang tersebut bukanlah termasuk ruang publik kota, pihak pemerintah kota juga tidak memiliki aturan yang dapat diberlakukan. Sehingga dari pihak pemerintahan hanya memberikan saran agar menggunakan ruang dengan baik dan tidak melakukan tindakan yang dapat merugikan masyarkat Kota Bandung. Dalam mengamanatkan pesan dari pemerintah Kota Bandung, klub motor membuat aturan main tersendiri mengenai penggunaan ruang tersebut. Waktu penggunaan ruang hanya dibatasi sampai pukul 11 (sebelas) malam dan tetap menjaga kebersihan tempat yang mereka gunakan.

Pada masa dua sampai tiga tahun terkahir ini, mulai banyak bermunculan klub motor yang lahir dari ruang di bawah flyover ini (lihat gambar 3). Hal ini pun menjadi titik awal semakin ramainya penggunaan ruang tersebut, sehingga terjadi usaha saling "berebut" diantara klub motor. Namun proses perebutan ruang tidak dilakukan dengan cara negatif, tetapi dengan cara negoisasi. Adanya sikap tenggang rasa dan saling menghargai antar klub motor merupakan salah satu wujud negoisasi yang ditujukan untuk menghindari konflik.

Bagi klub motor yang baru terbentuk, idealnya ialah mencari ruang yang masih tidak dimiliki oleh klub lainnya. Cara negoisasi ruang yang dilakukan ialah dengan cara menghubungi tiap klub motor yang telah lebih lama menempati ruang tersebut. Dengan cara tersebut, klub motor yang baru akan mendapatkan celah hari dan waktu dimana ruang yang mereka inginkan dapat mereka tempati. ruang yang mereka inginkan dapat mereka tempati. ruang yang mereka inginkan dapat mereka tempati. Namun, apabila klub baru tersebut tidak dapat mendapatkan waktu dan hari yang cocok di ruang tersebut, maka ada kecenderungan klub tersebut akan mencari ruang lainnya di dalam Kota Bandung.
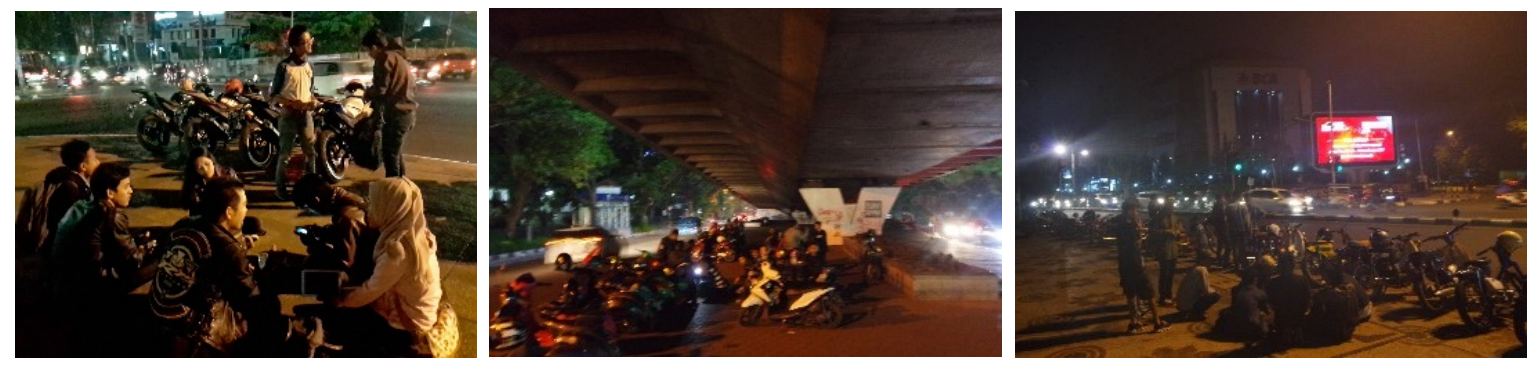

Gambar 3. Beberapa klub motor baru yang tercipta di ruang di bawah flyover Pasupati Bandung

Fenomena bahwa adanya proses pengokupasian ruang terbuka publik oleh klub motor di Kota Bandung merefleksikan dua kondisi yang dapat menjadi masukan bagi perencanaan ruang publik di Kota Bandung di masa depan. Kondisi pertama yaitu adanya proses penciptaan tempat (place-making) yang dilakukan oleh klub motor terhadap ruang yang tidak digunakan di Kota. Dengan tidak adanya identitas tetap pada ruang dibawah flyover tersebut, beberapa kegiatan yang dapat dinyatakan terbatasi dalam aturan kota dapat terungkap di ruang tersebut. Sehingga ruang ini bersifat lebih terbuka untuk diinterpretasi dan dimaknai oleh penggunanya.

Keberadaan subkultur klub motor ditengah-tengah masyarakat Kota yang masih dianggap negatif, membuat subkultur ini tidak dapat mengakses ruang publik kota dengan bebas. Oleh karena itu, keberadaan ruang-ruang tanpa identitas tersebut menjadi penting bagi eksistensi subkultur klub motor di Kota Bandung.

Penggunaan ruang tanpa identitas ini oleh subkultur klub motor pada akhirnya memberikan makna bagi ruang tersebut sehingga tidak berakhir menjadi ruang tanpa 
makna. Kemampuan subkultur untuk memberikan makna pada ruang tersebut seperti dijelaskan oleh Doron (2000) sebagai berikut:

"Unlike architects and planners who produce only representations of the urban environment and the objects within it, these individuals actually produce an alternative space. These transgressive actors and their activities work within implied systems of order to reveal the latent potential within these spaces that are overlooked and hidden, 'underneath the maps and outside the discourse'" (Doron: 2000).

Kondisi kedua yang dapat diamati dari fenomena tersebut ialah adanya kecenderungan legitimasi kekuasaan atas ruang. Kecenderungan tersebut pada akhirnya menghilangkan unsur bebas dan demokrasi dari ruang tersebut yang pada awalnya merupakan ruang bebas tanpa pemilik. Zukin (1996) menyatakan praktik seperti ini sebagai privatisasi ruang publik. Hal tersebut terkait dengan transformasi ruang-ruang terbuka yang beralih kepada kepemilikan termasuk pula terjadinya kontrol akses terhadap ruang publik.

Walaupun pada saat wawancara klub motor tersebut tidak merasa melakukan kegiatan privatisasi ruang publik, akan tetapi karena adanya kegiatan yang dilakukan secara rutin dan terus menerus di tempat tersebut, secara tidak langsung mereka telah membangun citra dan identitas ruang tersebut. Dari adanya praktek negosiasi yang dilakukan oleh klub motor yang lebih lama dan baru, memperlihatkan adanya legitimasi kekuasaan atas ruang publik tersebut.

Dari dua kondisi yang dapat dipelajari dari fenomena kehadiran subkultur di ruang publik Kota Bandung tersebut, maka perencanaan ruang publik Kota Bandung sebaiknya bercermin pada kondisi tersebut. Keberadaan subkultur yang selalu ada dalam suatu budaya perkotaan sebaiknya tidak diperlakukan sebagai suatu komunitas marjinal yang tidak punya hak atas ruang publik kota. Hal ini akan mengakibatkan subkultur tersebut akan mencari ruang mereka sendiri dalam kota dan melakukan legitimasi kekuasaan pada ruang tersebut.

Ruang publik merupakan gambaran ideal Habermas atas demokrasi. Prinsip yang dipandang baik oleh tradisi yang demokratis adalah nilai keadilan, keragaman, kebebasan, dan solidaritas. Konsep keadilan dan keragaman berarti ada kebutuhan bagi pluralisme budaya dan representasi bagi begitu banyak opini publik, praktik budaya, dan berbagai kondisi geografis dan sosial.

Ruang publik kota yang baik seharusnya dapat kembali pada sifat bebas dan demokratifnya, yang artinya ruang publik tersebut bebas diakses oleh siapa saja dan terjalin hubungan interaksi antara masyarakat sebagai penggunanya. Adanya kontrol berlebihan terhadap ruang publik malah hanya akan mengurangi akses ke ruang publik tersebut

\section{Simpulan}

Klub motor di Bandung merupakan salah satu subkultur yang memiliki sejarah yang sudah panjang. Klub motor ini, dibentuk karena adanya kesamaan dalam kepemilikan suatu jenis produksi motor tertentu. Klub motor merupakan suatu organisasi yang terorganisir dan memiliki berbagai kegiatan yang positif, berbeda dengan geng motor yang lebih dikenal dengan perilaku negatif.

Kehadiran subkultur klub motor di ruang terbuka publik di Kota Bandung merupakan suatu fenomena yang disebabkan oleh tidak tersedianya ruang publik kota yang dapat memenuhi kebutuhan mereka. Oleh karena itu, klub motor tersebut mencari wadah (ruang) sendiri dengan mengokupasi ruang-ruang "sisa" yang tanpa identiitas, 
artinya suatu ruang yang tidak diperuntukkan untuk fungsi apapun dalam kota. Subkultur pada akhirnya memberikan makna pada ruang tersebut, sehingga tidak sekedar menjadi ruang yang tidak berguna.

Fenomena tersebut memberikan refleksi terhadap perencanaan ruang terbuka publik kota yang lebih demokratis dan bebas bagi penggunanya. Arsitek dan pengambil kebijakan dalam perencanaan ruang publik kota, seharusnya mempertimbangkan kehadiran subkultur sebagai bagian dalam masyarakat yang juga mempunyai hak yang sama dalam penggunaan ruang terbuka publik.

\section{Daftar Pustaka}

Doron, G. (2000). The Dead Zone and the Architecture of Transgression. City, 4, 2 247-263

Rahma, S., \& Somaatmadja, A. S. (2013). Potensi Pemanfaatan Ruang di Bawah Jalan Layang. Jurnal Fakultas Teknik Universitas Indonesia

Santoso, J., 2006, Kota Tanpa Warga, Penerbit KPG dan Centropolis, Jakarta

Susanti, Wiwik Dwi. (2014). Faktor-Faktor Yang Mempengaruhi Pemanfaatan Ruang Terbuka Publik Di Bawah Jembatan Layang (Studi Kasus: Ahmad Yani, Kota Malang). Jurnal Envirotek, 6(1), 29

Wicandra, Oded Bima. (2013). Merebut Kuasa atas Ruang Publik: Pertarungan Ruang Komunitas Mural di Surabaya. Universitas Kristen Petra Surabaya

Zukin, S. (1996). The Culture of Cities. Oxford: Blackwell. 